\title{
Applications of Nucleoside-based Molecular Probes for the in vivo Assessment of Tumour Biochemistry using Positron Emission Tomography (PET)
}

\author{
Leonard I. Wiebe* \\ Edmonton PET Centre, Cross Cancer Institute, Edmonton, Canada T6G $1 Z 2$
}

\begin{abstract}
Positron emission tomography (PET) is a non-invasive nuclear imaging technique. In PET, radiolabelled molecules decay by positron emission. The gamma rays resulting from positron annihilation are detected in coincidence and mapped to produce three dimensional images of radiotracer distribution in the body. Molecular imaging with PET refers to the use of positron-emitting biomolecules that are highly specific substrates for target enzymes, transport proteins or receptor proteins. Molecular imaging with PET produces spatial and temporal maps of the targetrelated processes. Molecular imaging is an important analytical tool in diagnostic medical imaging, therapy monitoring and the development of new drugs. Molecular imaging has its roots in molecular biology. Originally, molecular biology meant the biology of gene expression, but now molecular biology broadly encompasses the macromolecular biology and biochemistry of proteins, complex carbohydrates and nucleic acids. To date, molecular imaging has focused primarily on proteins, with emphasis on monoclonal antibodies and their derivative forms, small-molecule enzyme substrates and components of cell membranes, including transporters and transmembrane signalling elements. This overview provides an introduction to nucleosides, nucleotides and nucleic acids in the context of molecular imaging.
\end{abstract}

Key words: Molecular biology, molecular imaging, PET, nucleosides, nucleotides, nucleic acids, oligonucleotides, antisense, aptamer, spiegelmer

\section{INTRODUCTION}

Contemporary language confers several meanings to the word cancer. In astronomy, it refers to a heavenly constellation observed near Leo and Gemini in the northern skies. In astrology cancer is the fourth sign of the zodiac, and in biology and astrology, cancer is synonymous with the crab, comprising the family of ten-legged crustaceans. Most commonly, however, cancer refers to malignant neoplasms characterized by the invasive, metastatic proliferation of undifferentiated cells. The properties of cancerous cells are attributed to the expression of mutations in their cellular deoxynucleic acid (DNA). Quite understandably, nucleic acid biochemistry is a primary target of cancer research.

Despite almost a century of research into hereditary principles, the link between cancer and DNA is not fully understood. DNA was first reported by Friedrich Miescher in 1869 (Miescher 1871), but its genetic role was only ascertained through several decades of probing research and inquiry. Erwin Schrödinger, in contemplation of the durability of hereditary molecules, asked the metaphysical question 'What is Life?'

\footnotetext{
* Author for correspondence
} 
(Schrödinger, 1944), following Oswald Avrey's report on the nature of the 'transforming principle' (DNA, 2005). In the early 1950's, Watson and Crick defined DNA's double helix structure (Watson and Crick, 1953; Franklin and Gosling, 1953). The field of molecular biology originally concerned the biology of gene expression, but now broadly includes macromolecular biology and biochemistry, including proteins, complex carbohydrates and nucleic acids. (Crick, 1970) Clearly, these and other investigations were stepping stones to modern molecular biology. Non-the-less, despite achievements such as sequencing the complete genomes of several species including man, many of DNA's secrets remain to be unravelled (Double Helix at 50, 2003). A comprehensive understanding of molecular biology is certain to be the key to combating cancer.

The structure, function and 'downstream' biochemistry of DNA, DNA expression (transcription to ribonucleic acid (RNA) and RNA translation to protein) are touchstones of contemporary molecular biology, which in turn, hold the keys to the biochemistry and genetics of cancer cells. Undoubtedly, molecular biology represents the best and perhaps only rational means to develop effective cancer therapies. The number and complexity of molecular interactions at the cellular level, together with the large number of potential DNA mutations that could lead to cancer, preclude the discovery of simple solutions to eradicate this disease.

Molecular imaging and functional imaging contribute to a better understanding of molecular events at cell and tissue levels. Appropriate molecular probes, together with in vivo (fMRI/MRS, PET, SPECT, sonography, optical imaging) and in vitro (confocal, fluorescence and electron microscopy) imaging techniques, are now used routinely to trace molecular events at the cellular level. In the medical clinic, these approaches can provide a molecular basis to select effective treatment and to monitor the patient's response to the therapy.

Two-dimensional (2-D) and three-dimensional (3D) images can provide both spatial and temporal information about functional processes. PET, in contrast to other in vivo imaging techniques, has the intrinsic ability to provide quantitative information at relatively high spatial resolution. In comparison to non-radiotracer imaging, PET can be used to monitor processes at physiological concentrations, because it can be a million times more sensitive than MRI (Paans et al, 1985). This is particularly important for the study of ligandreceptor interactions and neurotransmitter function, where nanomolar and picomolar concentrations are commonplace. Furthermore, the kinetic models derived from in vivo PET images frequently enable superior interpretation of qualitative images by quantifying a specific underlying biochemical process.

The spatial resolution of in vivo imaging equipment $\left(<0.1 \mathrm{~mm}^{3}\right.$ for MRI and and approaching $1 \mathrm{~mm}^{3}$ for high resolution PET), signal contrast and signal acquisition time (temporal resolution) are substantive limitations of current imaging devices. In vivo imaging currently provides averaged data derived from thousands or millions of cells, even at the highest resolution (the smallest volume element, or voxel, of the 3-D image). Furthermore, data for image reconstruction are collected over periods of time that may be long relative to the biological process under observation. Fortunately, imaging instrumentation is not yet fully developed: the temporal and spatial resolution, contrast sensitivity, and reconstruction algorithms have not yet reached their theoretical limits, and improvements on both fronts are continuing. Importantly, computing power now supports real time data analysis. Excellent reviews on the status of imaging are available (Apisarnthanarax and Chao, 2005; Seddon and Workman, 2003, Diagnostic radiology research, 2005).

\section{Targets For Molecular Imaging}

\section{Cell cycle}

Cells are the smallest independent biological entities capable of performing all of the functions required for life as we know it Fig. 1).

Dynamic events within and among cells provide the best opportunity to obtain functional information at the molecular level. In the simplest model, cell replication involves a complex sequence of events which are conventionally grouped into five stages: G0, G1, S, G2 and M. DNA synthesis occurs during $S$ phase, and the final division into two daughter cells is completed at the end of $\mathrm{M}$ phase.

Differentiated cells, which are cells that will not divide again, are in G0. The transition from G0 to G1 commits the cell to completing the cycle (The Dictionary of Cell and Molecular Biology, 2005). 
DNA transcription and RNA translation are prime molecular imaging/radiotherapeutic targets for identifying and monitoring proliferating (cycling) cells.

Cell proliferation involves all aspects of cellular metabolism. Cell proliferation markers, including molecular imaging radiopharmaceuticals, could potentially reflect protein synthesis, energy consumption, or DNA synthesis (Fig. 2). Neverthe-less, markers of S-phase activity, which reflect the doubling of DNA in preparation for division, are considered the most accurate indicators of proliferation.

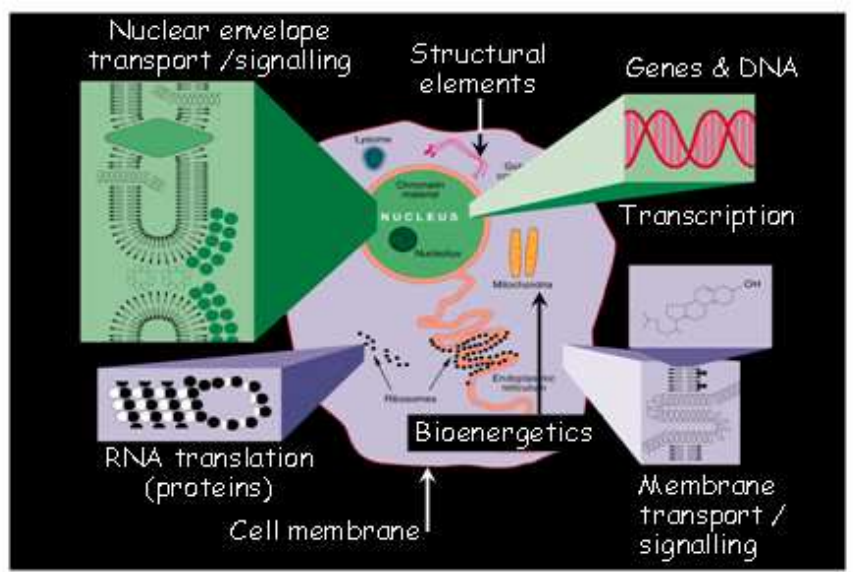

Figure 1 - Schematic representation of a eukaryotic cell depicting molecular processes that are potentially suitable for molecular imaging.

\section{Cell migration and metastasis}

Cell migration is an integral part of life, from embryonic morphogenesis to the recruitment of immune responses and repair in adult tissues. Cell migration and colonization (metastasis) in new tissue is a hallmark of cancer. Metastatic tumors may express molecular features that differ from cells in the primary colony, often making them difficult to detect and treat using techniques/reagents that were effective for the primary tumor. Relocation to sites that may be difficult to access, and the expression of molecular changes (e.g. surface antigens) make these socalled secondary tumors the major challenge to successful treatment of cancer. Potential diagnostic/imaging targets include chemotactic molecules that signal migration, actin polymerization associated with identification of new terrain, and adhesive complexes needed for traction.

\section{Cell biochemistry}

The design of diagnostic molecular probes is frequently based on drugs which have favorable therapeutic or pharmacological properties. Unfortunately, many drugs have broad biodistributions within the body, several sites of action, and pharmacokinetic properties incompatible with imaging.

Cell homeostasis is based on complex, dynamic, interdependent molecular reactions. Moreover, genome expression is bioenergetically driven from within the genomic code, so that the beginning and end of a cell's life cycle look remarkably similar. Major points of interaction between diagnostic radiopharmaceuticals and a simple homeostatic model are shown in Fig. 2. The three major components are:

- The genome, i.e., nucleosides, nucleotides, oligonucleotides, polynucleotides and nucleic acids,

- The proteome, i.e., proteins (enzymes, receptors, structural elements, antibodies, etc), and

- The energy sources, i.e., glucose, acetate and fatty acids.

Molecular imaging of these systems using true substrates (e.g., $\left[{ }^{11} \mathrm{C}\right]$ glucose for pathologies that reflect altered glucose metabolism) provides complex data because the signal (counts per voxel or pixel) reflects total radioactivity. Counts represent the sum of signals derived from all 
radioactive species present, e.g., the substrate and its radioactive metabolites. Deconvolution of this complex information into its biochemical components is simply too difficult, tedious and time-consuming to be practical in a clinical setting.

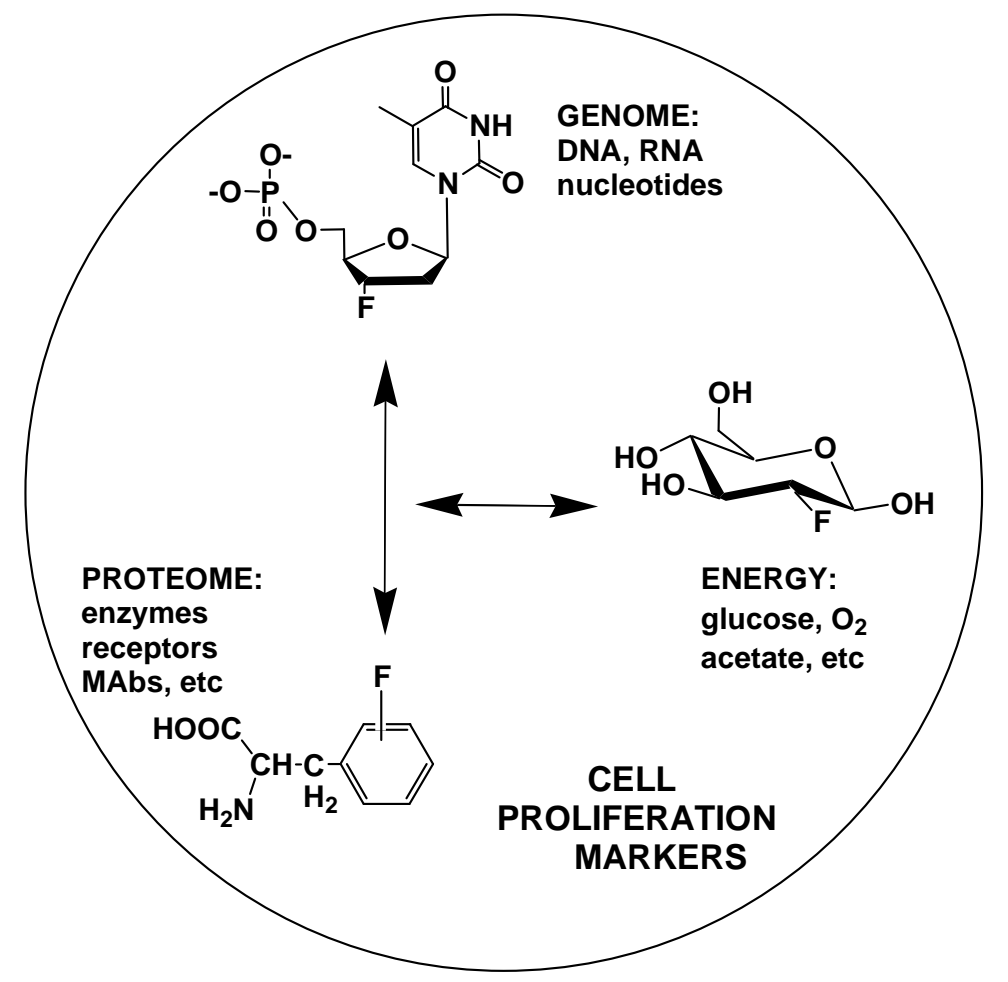

Figure 2 - Fluorinated amino acids, carbohydrates and nucleosides are false substrates used for molecular imaging of cell proliferation processes.

Fortunately, false substrates and mimics such as 2$\left[{ }^{18} \mathrm{~F}\right]$ fluorodeoxyglucose $\left(2-\left[{ }^{18} \mathrm{~F}\right] \mathrm{FDG}\right)$, which only partially enter the biochemical pathway of interest, can be used to simplify data interpretation. Full validation of data from false and natural substrates, and mimics, is necessary to ensure that images and parametric image data accurately reflect the molecular process of interest and lead to an accurate clinical diagnosis.

In oncology, tumor cell growth, proliferation and metastasis attract the greatest interest both for diagnosis and therapy. These cellular processes are energy dependent, and because glucose is a major energy source, it is a logical substrate to use as a marker of cell activity. The transmembrane transport and phosphorylation (metabolic trapping) of glucose are both energy consuming in themselves, but more importantly, these processes combine to provide high uptake of the tracer, with a strong concentration differential to blood, thereby producing a high contrast image that is easy to interpret. However, the universality of glucose consumption in all proliferating (e.g., marrow) and 'working' cells (e.g., brain, exercising muscle) can mask cancer cell activities such as the phosphorylation of glucose. Although radiolabelled glucose analogues would therefore seem to be too universal for studies of cellular metabolism in a pathological setting, the clinical success of PET derives from 2-[ $\left[{ }^{18}\right.$ F]FDG, which mimics the phosphorylation of glucose. (Wiebe, 2001).

\section{Nucleosides and Nucleotides}

Nucleosides are glycosides formed through covalent bonding between the anomeric $(\mathrm{C}-1)$ carbon of the pentose sugars D-ribose or D-2deoxyribose and either the $\mathrm{N}-1$ nitrogen atom of pyrimidine or purine bases. The natural 'biological' nucleoside (sugar-base) bond has the beta or 'up' configuration at C-1, relative to the plane of the sugar. The common bases in DNA are adenine (A), guanine $(\mathrm{G})$, thymine $(\mathrm{T})$ and 
cytosine $(\mathrm{C})$, linked to deoxyribose, and in RNA are A, G, C and uracil (U), linked to ribose (Fig. 3).<smiles>Nc1ncnc2c1ncn2[Ga]Br</smiles><smiles>Cn1cnc2c(=O)[nH]c(N)nc21</smiles>

PURINE BASES

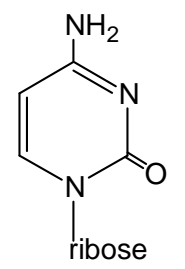<smiles>Cc1cn(C(=O)O)c(=O)[nH]c1=O</smiles>

thymine<smiles>O=c1ccn([Ga])c(=O)[nH]1</smiles>

PYRIMIDINE BASES

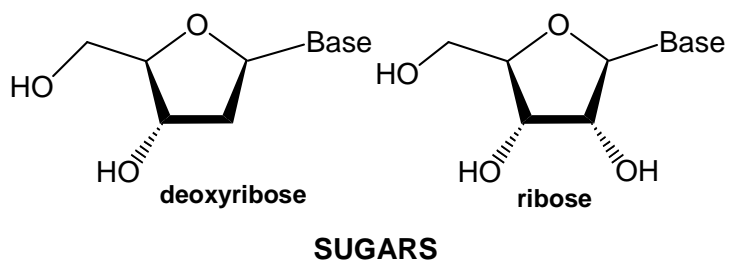

Figure 3 - The purine and pyrimidine nucleobases and sugars present in natural nucleic acids.

The development of radiopharmaceuticals for cancer detection, cell proliferation measurement and gene therapy monitoring has focused heavily on the pyrimidine nucleobases thymine and uracil. Radiochemists first radiolabelled thymidine with carbon-14 in the early 1950 's, and this work was extended into diagnostic nuclear medicine with the synthesis of $\left[{ }^{11} \mathrm{C}\right.$-methyl]thymidine in 1972 (Christman et al, 1972). Although this is theoretically the ideal proliferation-imaging radiotracer, its rapid and complex metabolism mitigates against its routine use as a PET radiotracer. A robust analytical model that clears the way for the interpretation of $\left[{ }^{11} \mathrm{C}\right]$ thymidine PET data has been reported (Wells et al, 2002a, 2002b).

\section{Halothymidine analogues of thymidine}

The first reported radioiodinated analogues of thymidine were $5-\left[{ }^{131} \mathrm{I}\right]$ iodouridine (IUR) (Prusoff et al, 1953) and 5-[ $\left.{ }^{131} \mathrm{I}\right]$ iodo-2'-deoxyuridine (IUdR) (Prusoff 1959). Recurring interest in IUdR, a bioisostere of thymidine, is due to its wellunderstood chemistry, biochemistry and pharmacology. Unfortunately, the 5-bromo-, 5iodo- and 5-astato- analogues all suffer from poor uptake/reutilization (< $5 \%$ \%) compared to thymidine (the natural substrate) as well as rapid and extensive catabolism. Numerous (radiolabelled) catabolites greatly complicate image interpretation and add substantially to the radiation burden in non-target tissues. The radiotherapeutic potential of $5-\left[{ }^{211}\right.$ At $]$ astato-2'deoxyuridine ( $\alpha$-particle emitter) (Vaidyanathan et al, 1996) and particularly 5-[ $\left.{ }^{125} \mathrm{I}\right]$ iodo-2'deoxyuridine (Auger electron emitter) (Semnani et al, 2005) has prompted recent interest in these thymidine analogues, but without innovative sitespecific delivery of appropriate formulations, these compounds seem unlikely to find use as routine radiotherapeutic agents. 5-Halo-nucleosides and selected properties are shown in Fig. 4.

Of the 5-halo-analogues of thymidine, 5-fluoro-2'deoxyuridine (FUdR) (Heidelberger et al, 1957, 
1983) is of special interest. Like its 5-halo relatives, it is phosphorylated at C-5' by thymidine kinase to 5-fluorodeoxyuridylate (FDUMP), which is not facilely inserted into DNA, but which is a strong inhibitor of thymidine synthase (TS) (Danenberg et al, 1981). As a TS inhibitor, FUDMP prevents the methylation of uridylate to thymidylate and hence exerts strong cellular toxicity by inducing thymidine starvation in treated cells (Langenbach et al, 1972). Although not selective for cancer cells, this mechanism is at least partially responsible for the antitumor effects of FUdR and the nucleobase fluorouracil (FU; Fig. 5) which is used extensively in current chemotherapy of colorectal cancer (Lawes and Taylor 2005). $\left[{ }^{18} \mathrm{~F}\right] \mathrm{FU}$, first radiolabelled in 1973 (Fowler et al, 1973), has been shown to have utility in the prediction of tumor susceptibility to FU therapy (Dimitrakopoulou 1993; Dimitrakopoulou-Strauss 1998) but surprisingly this protocol is not used routinely to select and monitor cancer therapy.

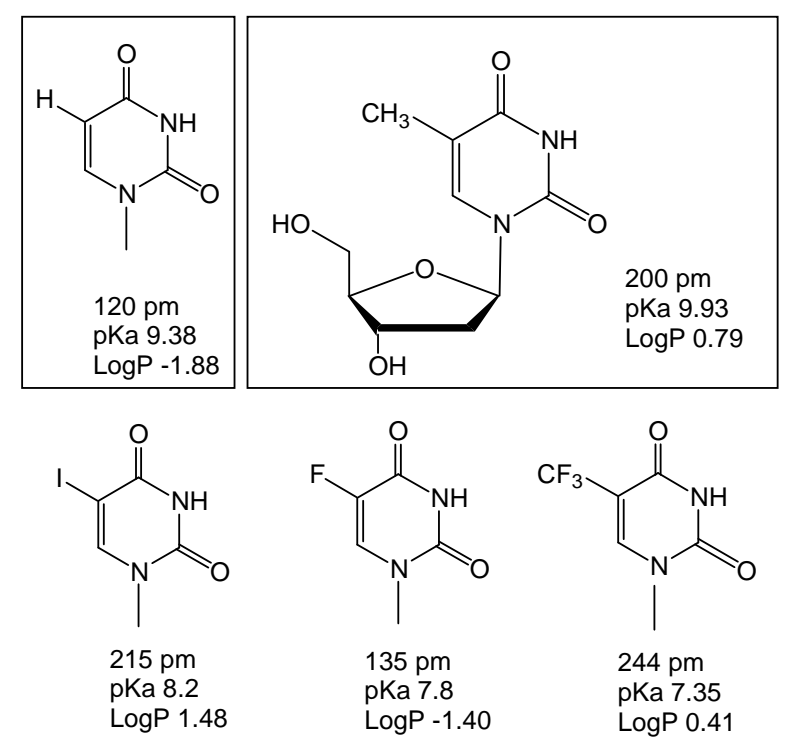

Figure 4 - Properties of C-5- substituted pyrimidine deoxynucleosides; pm (atomic radius in picometers), pKa (N-3 H acidity), LogP (partition coefficient).

Thymidine analogues with modified/fluorinesubstituted ribose sugars

Nucleoside analogues can also be constructed by chemical alteration of the sugar moiety. Common approaches include insertion of a heteroatom (e.g., F) in place of $-\mathrm{H}$ or $-\mathrm{OH}$, insertion of $-\mathrm{H}$ in place of $-\mathrm{OH}$ (deoxy sugars), inversion of configuration at a chiral carbon (e.g., C-2' or C-3'), replacement of the (deoxy)ribofuranosyl sugar altogether and adding a short-chain aliphatic chain in its place (e. g., acyclovir; Elion, 1980), L-sugars, or replacement of the ring oxygen atom by $\mathrm{C}$ or $\mathrm{S}$. The sugar carbon atoms are numbered 1', 2', 3', 4', and $5^{\prime}$ to distinguish them from the numbering of the atoms of the purine and pyrimidine bases.

An example of replacing the ring oxygen of the ribofuranose moiety by a heteroatom is provided in the design and radiolabeling of 5-[ $\left.{ }^{125} \mathrm{I}\right]$ iodo-4'- thio-2'-deoxyuridine ([ $\left.\left.{ }^{125} \mathrm{I}\right] \mathrm{ITdU}\right) \quad$ (Fig. 5). $\left[{ }^{125} \mathrm{I}\right] \mathrm{ITdU}$ is reported to be less susceptible to catabolism than IUdR and readily incorporated into DNA in proliferating tissues in vivo (Toyohara et al, 2003).

\section{Other thymidine mimics}

Replacement of the base with a suitable 'pseudobase', for example, replacing the thymine moiety with a 5-methyl-2,4-difluorophenyl- or isostyryl- groups has been used to produce chemically stable analogues (Al-Madhoun et al, 2004).

Selected design options for thymidine analogues and mimics are depicted in Fig. 6.

A full discussion of nucleoside analogues lies well beyond the scope of this review, but radiolabelled nucleosides for gene therapy monitoring and cell 
proliferation monitoring deserve additional

comment.<smiles>O=c1[nH]cc(F)c(=O)[nH]1</smiles>

FU

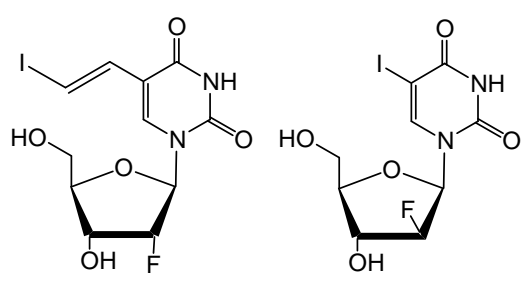

IVFRU

FIAU
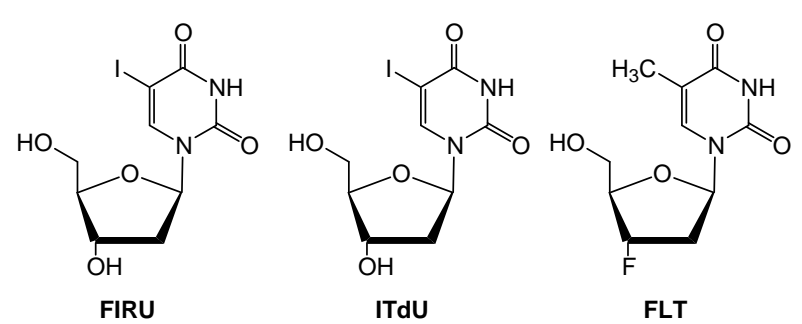

Figure 5 - Pyrimidine nucleosides for cell proliferation and gene therapy monitoring.

\section{Monitoring gene therapy}

An effective strategy has been the insertion of $-\mathrm{F}$ at C-2'. This invokes two stereochemistries, the 'up' or arabino or the 'down' or ribo configurations. In the case of the C-2'-fluorinated analogues of IUdR, this gives rise to 1-(2-deoxy-2fluoroarabinofuranosyl)-5-iodo-uracil (FIAU) and 1-(2-deoxy-2-fluororibo-furanosyl)-5-iodouracil (FIRU), respectively. These molecules are resistant to phosphorolysis (hydrolysis of the nucleoside bond) and are poorly phosphorylated by nuclear thymidine kinase. The first reported nucleosides for monitoring expression of the herpes virus type-1 thymidine kinase (HSV-1 TK) gene were (E)-1-(2-fluoro-2deoxyarabinofuranosyl)-5-(2-iodovinyl)-uracil

(IVFAU) and (E)-1-(2-fluoro-2-deoxyribofuranosyl)-5-(2-iodovinyl)-uracil

(IVFRU)

(Iwashina et al, 1988; Balzarini et al, 1995) (Fig. 5). The C-5 iodo analogues FIAU (Tjuvajev et al 1996) and FIRU (Tovell et al, 1988; Wiebe et al, 1999) are equally effective, and the radiolabelling workup for the latter is simpler than for the $(E)-5$ (2-iodovinyl)- analogues because the stereochemistry around the vinyl group is critical to efficacy of the product. Care must be taken while radioiodinating the precursor, to avoid forming the the $(Z)$-isomer, which is inactive. Much of the more recent literature on HSV-1 TK gene therapy imaging with PET has utilized $\left[{ }^{18} \mathrm{~F}\right]$ purine nucleosides. This literature is extensive, and interested readers are referred to several excellent reviews (Yaghoubi 2005; Haberkorn, 2005; Couturier, 2004).

\section{Cell proliferation imaging}

3'-Fluoro-3'-deoxythymidine (FLT) (Fig. 5), despite being today's most popular cell proliferation imaging agent, has several biochemical shortcomings. It is incorporated into DNA after phosphorylation, causing chain termination (Langen et al, 1969) and it is cytotoxic (Matthes 1988) due to its phosphorylation by both Type-1 (nuclear) and Type-2 (mitochondrial) thymidine kinases; e.g., it is only partially selective for nuclear thymidine kinase and therefore sends a mixed message about replicative DNA synthesis. Despite these limitations, $\left[{ }^{18}\right.$ F]FLT (Shields et al 1998) has been validated (Grierson et al, 2004, Muzi et al, 2005) as a proliferation marker and is now widely accepted as a cell proliferation for PET (Been et al, 2004). Recent reviews are available (Mankoff et al, 2005; Colozza et al, 2005). Nucleotides are nucleosides with one or more phosphate groups covalently attached to the 3'- and/or 5'-hydroxyl group(s) of the sugar. Single nucleotides are generally not useful as either drugs or radioimaging agents because they are highly susceptible to phosphorolysis in plasma and tissue, which 
converts them back to the non-phosphorylated nucleoside. Furthermore, both the mono-, di- and tri-phosphate esters, and the phosphodiesters of polynucleotides carry negative charges at physiological $\mathrm{pH}$, effectively precluding their diffusive passage across cell membranes. Nucleotide transporters have not been characterized to date. For in vivo use, nucleotide drugs and radiopharmaceutical, must be specially formulated for facile entry into target cells. Readers interested in the formulation of oligonucleotides are referred to the extensive literature (Park et al, 2004; Simeoni et al, 2005).

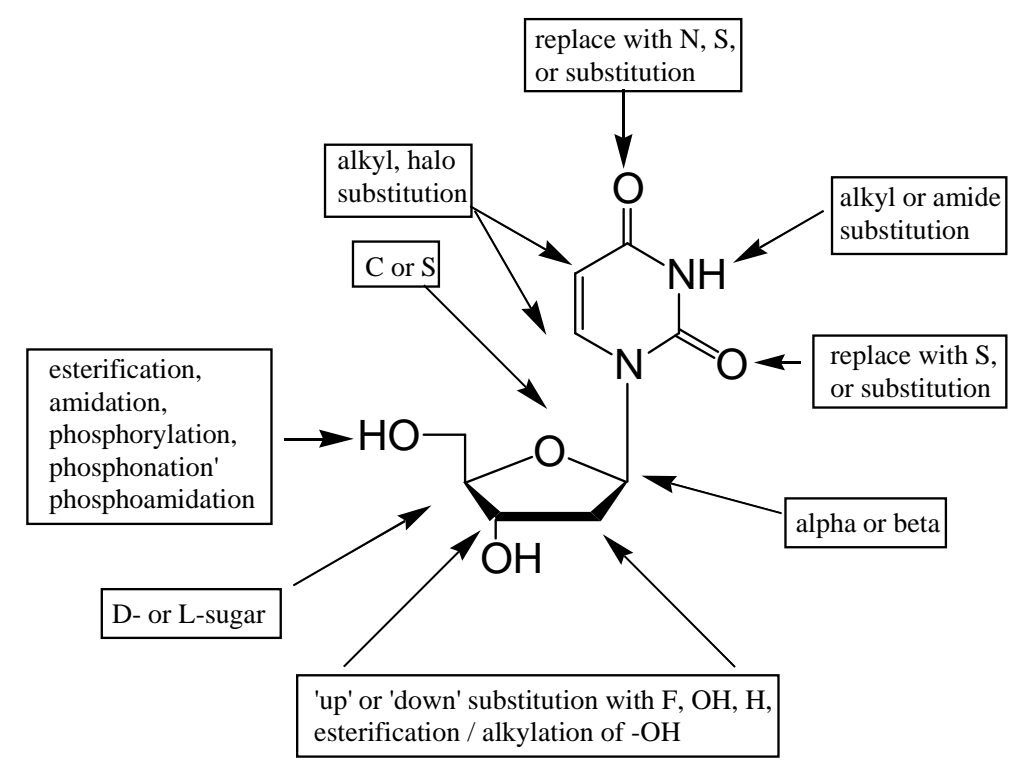

Figure 6 - Sites for chemical modification of pyrimidine nucleosides, using 2'deoxyuridine as a model.

\section{Oligonucleotides and Nucleic Acids}

The nucleic acids deoxynucleic acid (DNA) and ribonucleic acid (RNA), and oligonucleotides, are polymers formed via $3^{\prime} \rightarrow 5^{\prime}$ phosphodiester bonds joining these monomeric nucleotides in specific sequences.

These polymers are described chemically by listing the nucleotide sequence, using the abbreviation for the nucleobase, starting at the first nucleoside in the $3^{\prime} \rightarrow 5^{\prime}$ '-phosphodiester bridge; thus, the fragment in Fig. 7 would be designated $\mathrm{d}$ (TGCA), in which ' $\mathrm{d}$ ' designates it as a deoxypolymer.

All oligonucleotides, regardless of function, share one common trait: they are polymers of nucleosides that are linked through $3^{\prime} \rightarrow 5^{\prime}$ phosphodiester bonds. Thus, although antisense oligonucleotides are possibly the best known 'pharmacological' class of oligonucleotides, oligos of remarkably similar chemical structure can have remarkably different biochemical and pharmacological properties. Several classes of oligonucleotides are listed in Table 1.

A major impediment to the in vivo use of oligonucleotides is their facile degradation by hydrolytic enzymes (nucleases) in plasma and cytoplasm. Enhanced stability has been achieved through selective chemical modification, including the introduction of phosphorothioate and methylphosphonate bridges, ribose-2-Omethylation and replacement of the ribose sugar itself, for example, with 2'-O, 4'-O-ethylene bridges (Koizumi, 2004). 
Table 1 - Oligonucleotides and their unique function or properties.

\begin{tabular}{lll}
\hline $\begin{array}{l}\text { Oligonucleotide } \\
\text { Class }\end{array}$ & Function/property & $\begin{array}{l}\text { Radiopharmaceutical } \\
\text { References }\end{array}$ \\
\hline Antisense - RNA & $\begin{array}{l}\text { bind to specific sequences of an mRNA of interest } \\
\text { via Watson-Crick duplex formation to stop RNA } \\
\text { translation }\end{array}$ & $\begin{array}{l}\text { Bai et al, 2004; } \\
\text { Dewanjee et al, 1991, } \\
1994 ;\end{array}$ \\
& & $\begin{array}{l}\text { Roivainen et al, 2004; } \\
\text { Shi et al, 2000 }\end{array}$ \\
& & $\begin{array}{l}\text { Zhang et al, 2005; } \\
\text { Zheng et al, 2003a,b }\end{array}$ \\
Antisense - DNA & complementary binding to targeted DNA to stop & $\begin{array}{l}\text { Hnatowich et al, 1995 } \\
\text { DNA transcription }\end{array}$ \\
Aptamer & $\begin{array}{l}\text { recognize virtually any class of target molecules } \\
\text { (mimic antibodies); highly labile in plasma }\end{array}$ & $\begin{array}{l}\text { Charlton et al, 1997; } \\
\text { Dougan et al, 2003; } \\
\text { Pestourie et al, 2005 }\end{array}$ \\
$\begin{array}{l}\text { Triplex-forming } \\
\text { (TFO) }\end{array}$ & Sequence-specific binding to DNA & $\begin{array}{l}\text { Panyutin et al, 2003; } \\
\text { Sedelnikova et al, 2002 }\end{array}$ \\
\hline
\end{tabular}

Table 2 - Chemically-modified oligonucleotides: changes to the sugar/phosphate backbone.

\begin{tabular}{|c|c|c|}
\hline $\begin{array}{l}\text { Modified } \\
\text { oligonucleotide }\end{array}$ & Main chemical change & $\begin{array}{l}\text { Radiopharmaceutical } \\
\text { References }\end{array}$ \\
\hline $\begin{array}{l}\text { Morphilino } \\
\text { oligonucleotide } \\
\text { (MORF) }\end{array}$ & $\begin{array}{l}\text { morphilino moiety replaces ribose/deoxyribose to } \\
\text { provide biochemical stability }\end{array}$ & $\begin{array}{l}\text { Liu et al, } 2002 \\
\text { Mang'era et al, } 2001\end{array}$ \\
\hline Phosphorothioate & phosphorothioate substitutes for phosphodiester bridge & Hnatowich 1996 \\
\hline $\begin{array}{l}\text { Polyamide } \quad \text { nucleic } \\
\text { acid (PNA) }\end{array}$ & amino acid linker provides biochemical stability. & $\begin{array}{l}\text { Lewis et al, 2002; } \\
\text { Sun et al, 2005; } \\
\text { Tian et al, 2003; } \\
\text { Wilbur et al, 2005 }\end{array}$ \\
\hline $\begin{array}{l}\text { Arabinose-2-O- } \\
\text { fluorination (FANA) }\end{array}$ & $\begin{array}{l}\text { fluorination at arabino C-2'-O- decreases susceptibility } \\
\text { to hydrolysis by nucleases }\end{array}$ & Boisgard et al, 2005 \\
\hline Spiegelmer & $\begin{array}{l}\text { mirror image oligonucleotide through L-ribose/L- } \\
\text { deoxyribose; recognize target enantiomers; bind to } \\
\text { nucleosides, amino acids or peptides with high } \\
\text { affinity; stable in biological fluids }\end{array}$ & Boisgard et al, 2005 \\
\hline
\end{tabular}

The best example of the replacement approach is the introduction of morpholino replacements of ribose, creating oligonucleotides known as morpholino nucleotides (MORFS) (Fig. 8) that are not only stable in the presence of nucleases, but that also are uncharged and therefore easier to move across cell membranes (Summerton and Weller, 1997). The biological utility of MORFS was demonstrated in a study of sequence-specific inhibitors of in vitro mRNA translation, in which the morpholino oligomer M-AS 2 caused significant inhibition of TNF- $\alpha$ production by macrophages at low (nM) intracellular concentrations (Taylor et al, 1996).

Spiegelmers and polyamide nucleic acids (PNAs) are two of the many 'backbone' modifications (linking the nucleosides) developed to circumvent the limitations of natural oligonucleotides. 
Spiegelmers are oligonucleotides formed using Lribose or L-deoxyribose. The resulting mirrorimage L-DNA or L-RNA is insensitive to enzymatic degradation, and maintains the principles of reciprocal chiral substrate specificity. (Eulberg and Klussmann, 2003). Some molecular engineering is required to create spiegelmers that are selective for natural complimentary ligands
(Klussmann, 1996). Sugar modifications have also been introduced (Helmling et al, 2003). In PNAs the phosphodiester linkages between nucleosides are replaced by aminoethylglycyl linkages (Neilsen 1991).

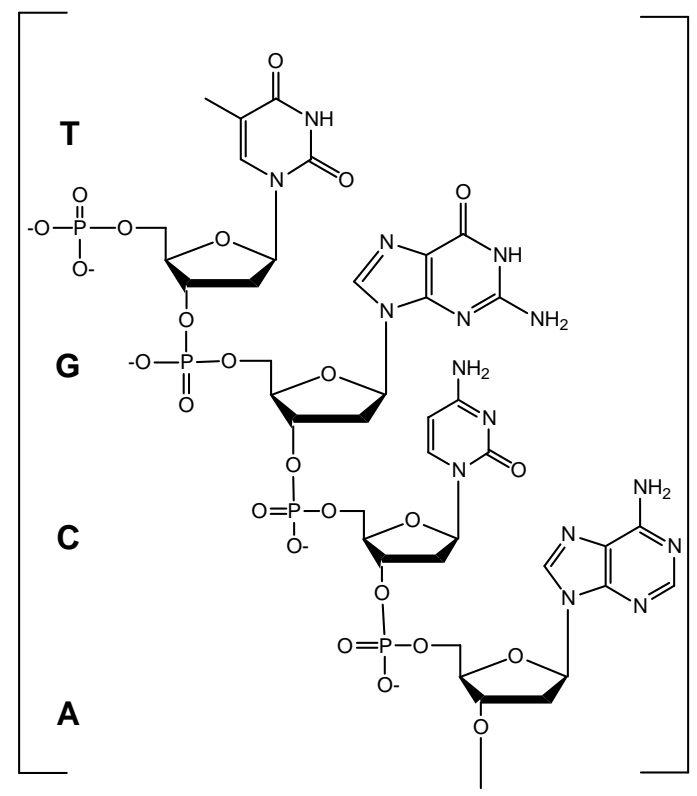

Figure 7 - 3' $\rightarrow$ 5'-Phosphodiester bridges link nucleosides in nucleic acids. DNA, RNA and oligonucleotides are members of this class of compounds. Bold letters designate the nucleobase; the sequence is designated as the deoxypolynucleotide $\mathrm{d}$ (TGCA).

PNAs are highly resistant to in vivo cleavage. Interested readers are referred to several excellent reviews for more detailed information on oligonucleotide modifications, mechanisms of action and their potential applications in medicine (Urban and Noe, 2003; Buchini and Leumann, 2003; Kurreck, 2003, Kaihatsu et al, 2004; Pellestor and Paulasova, 2004).

\section{Oligonucleotides in Nuclear Oncology}

Radiopharmaceutical scientists have been working with radioiodinated (Dewanjee et al, 1991) and metal-coordinated (Dewanjee et al, 1994; Hnatowich et al., 1995, 1996) antisense oligonucleosides for over a decade. Both Dewanjee (Dewanjee et al, 1999) and Hnatowich (Hnatowich 1996) published early reviews which compliment current literature (Younes et al, 2002) on aspects of oligonucleotide application in nuclear medicine. The problem of biological instability and transport across cell membranes has been investigated using liposomal formulations of ${ }^{99 \mathrm{~m}} \mathrm{Tc}$-labelled antisense oligonucleotides of cmyc mRNA (Zheng et al, 2003a, 2003b). In vivo imaging studies of atherosclerotic plaque and restenosis using antisense evaluated the uptake kinetics of radiolabeled oligonucleotides to the messenger RNA (mRNA) of proliferating cell nucleus antigen (PCNA) in vascular smooth muscle cells (VSMCs) (Zhang et al, 2005) and intracellular mdr1 mRNA expression detection with radiolabeled antisense oligonucleotide (ODN) (Bai et al, 2004) are representative of recently reported antisense studies. A ${ }^{68} \mathrm{Ga}$ labelled antisense oligonucleotide has recently been reported (Roivainen et al, 2004). 
The pioneering work of Dougan (Dougan et al, 1997), in which a radiolabeled nucleotide is added onto the aptamers sequence has initiated the development of aptamer radiopharmaceuticals. A similar approach has recently been reported for labeling a PNA sequence, this time adding the pyrimidine base iodouracil to the PNA chain (Wilbur et al,
2005). Tables 1 and 2 provide additional information on progress towards the utilization of oligonucleotides with a range of biochemical and pharmacological properties and a selection of the chemical derivative oligonucleotides currently available.
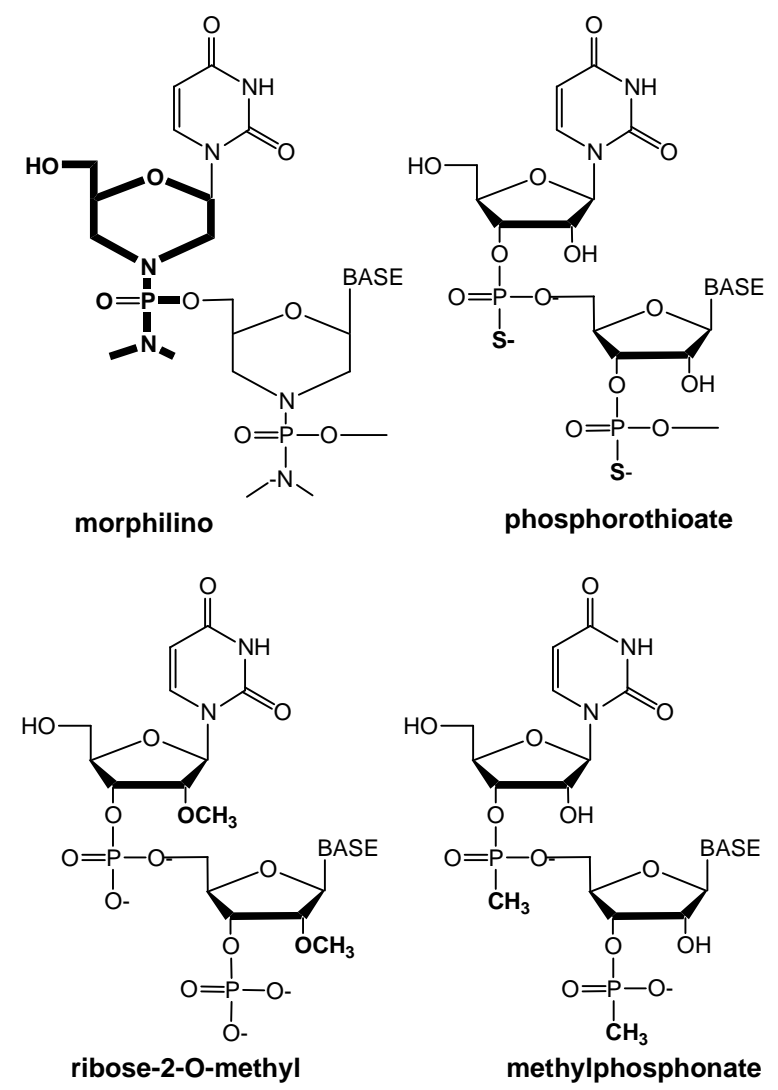

Figure 8 - The chemical structures of several backbone-modified oligonucleotide analogues.

\section{Summary}

Nucleosides, nucleotides and nucleic acids play a central role in cellular biochemistry. Their chemically-modified analogues are important tools in the development of an understanding of cellular processes, and their radiolabelled counterparts have the potential to assist in the management of cancer and other diseases in the context of diagnostic molecular imaging.

\section{RESUMO}

A tomografia por emissão de pósitrons (TEP) é uma técnica de imagem não invasiva da medicina nuclear. A TEP utiliza moléculas marcadas com emissores de radiação beta positiva (pósitrons). As radiações gama medidas que resultam do aniquilamento dos pósitrons são detectadas por um sistema de coincidência e mapeadas para produzir uma imagem tridimensional da distribuição do radiotraçador no corpo. A imagem molecular com TEP referese ao uso de biomoléculas marcadas com emissor de pósitron que são substratos altamente específicos para alvos como enzimas, proteínas transportadoras ou receptores protéicos. A 
imagem molecular com TEP produz mapas espaciais e temporais de alvos que estejam sendo avaliados. A imagem molecular é uma importante ferramenta analítica no diagnóstico por imagem em medicina, no monitoramento de terapia e no desenvolvimento de novas drogas. A imagem molecular tem seus fundamentos na biologia molecular. Originalmente, a biologia molecular significava a biologia da expressão gênica, mas atualmente a biologia molecular envolve amplamente a biologia de macromoléculas, a bioquímica de proteínas, carboidratos complexos e ácidos nucléicos. A imagem molecular tem priorizado as proteínas, com ênfase nos anticorpos monoclonais e suas formas derivadas, substratos enzimáticos para pequenas moléculas e componentes de membranas celulares, incluindo os transportadores e elementos envolvidos com a sinalização trans-membrana.

\section{ACKNOWLEDGEMENTS}

I wish to thank Professor Edward E Knaus for his collaboration in nucleoside chemistry and radiopharmaceutical chemistry, and acknowledge the financial support of the Medical Research Council of Canada and the Canadian Institutes of Health Research, over the past three decades. The invitation from Dr. Valbert N Cardoso, President of SBBN-2005, and his colleagues, to present this work in Belo Horizonte is greatly appreciated.

\section{REFERENCES}

Al-Madhoun, A. S., Eriksson, S., Wang, Z. X., Naimi, E., Knaus, E. E., Wiebe, L. I. (2004), Phosphorylation of isocarbostyril- and difluorophenyl-nucleoside thymidine mimics by the human deoxynucleoside kinases. Nucleosides Nucleotides Nucleic Acids, 23, 1865-1874.

Apisarnthanarax, S., Chao, K. S. (2005), Current Imaging Paradigms in Radiation Oncology. Radiat Res., 163, 1-25.

Bai, J., Yokoyama, K., Kinuya, S., Shiba, K., Matsushita, R., Nomura , M, Michigishi, T., Tonami, N. (2004), In vitro detection of mdr1 mRNA in murine leukemia cells with ${ }^{111}$ In-labeled oligonucleotide. Eur J Nucl Med Mol Imaging, 31, 1523-1529.
Balzarini, J., Morin, K W., Knaus, E. E., Wiebe, L. I. De Clercq, E. (1995), Novel (E)-5-(2-iodovinyl)-2'deoxyuridine derivatives as potential cytostatic agents against herpes simplex virus thymidine kinase gene transfected tumors. Gene Ther., 2, 317322.

Been, L. B., Suurmeijer, A. J., Cobben, D. C., Jager, P. L., Hoekstra, H. J., Elsinga, P. H. (2004), $\left[{ }^{18}\right.$ F]FLT-PET in oncology: current status and opportunities. Eur J Nucl Med Mol Imaging, 31, 1659-1672.

Boisgard, R., Kuhnast, B., Vonhoff, S., Younes, C., Hinnen, F., Verbavatz, J. M., Rousseau, B., Furste, J. P., Wlotzka, B., Dolle, F., Klussmann, S., Tavitian, B. (2005), In vivo biodistribution and pharmacokinetics of ${ }^{18}$ F-labelled Spiegelmers: a new class of oligonucleotidic radiopharmaceuticals. Eur J Nucl Med Mol Imaging, 32, 470-477.

Buchini, S., Leumann, C. J. (2003), Recent improvements in antigene technology. Curr Opin Chem Biol., 7, 717-726. Review.

Charlton, J., Sennello, J., Smith, D. (1997), In vivo imaging of inflammation using an aptamer inhibitor of human neutrophil elastase. Chem Biol., 4, 809-816.

Christman, D., Crawford, E. J., Friedkin, M., Wolf, A. P. (1972), Detection of DNA synthesis in intact organisms with positron-emitting [methyl [C-11]] thymidine. Proc Natl Acad Sci USA., 69, 988-992.

Colozza, M., Azambuja, E., Cardoso, F., Sotiriou, C., Larsimont, D., Piccart, M. J. (2005). Proliferative markers as prognostic and predictive tools in early breast cancer: where are we now? Ann Oncol published on June 24, doi:10.1093/annonc/mdi352.

Couturier, O., Chatal, J. F., Hustinx, R. (2004), Fluorinated analogs of nucleosides and fluorinated tracers of gene expression for positron emission tomography. Bull Cancer, 91, 695-703.

Crick, F. (1970), Central Dogma of Molecular Biology. Nature 227, 561-563.

Danenberg, P. V., Heidelberger, C., Mulkins, M. A., Peterson, A. R. (1981), The incorporation of 5fluoro-2'-deoxyuridine into DNA of mammalian tumor cells. Biochem Biophys Res Commun., 30, 654-658.

Dewanjee, M. K., Ghafouripour, A. K., Kapadvanjwala, M., Dewanjee, S., Serafini, A. N., Lopez, D. M., Sfakianakis, G. N. (1994), Noninvasive imaging of c-myc oncogene messenger RNA with indium-111-antisense probes in a mammary tumor-bearing mouse model. $\mathrm{J} \mathrm{Nucl}$ Med., 35, 1054-1063.

Dewanjee, M. K., Ghafouripour, A. K., Werner, R. K., Serafini, A. N., Sfakianakis, G. N. (1991), Development of sensitive radioiodinated anti-sense oligonucleotide probes by conjugation technique. Bioconjug Chem., 2, 195-200. 
Dewanjee, M. K., Haider, N., Narula, J. (1999), Imaging with radiolabeled antisense oligonucleotides for the detection of intracellular messenger RNA and cardiovascular disease. $\mathrm{J} \mathrm{Nucl}$ Cardiol., 6, 345-356. Review.

Diagnostic radiology research. (2005), NIH, USA. http://www.cc.nih.gov/ldrr/htmlpg/Initiatives.html.

Dimitrakopoulou, A., Strauss, L. G., Clorius, J. H., Ostertag, H., Schlag, P., Heim, M., Oberdorfer, F., Helus, F., Haberkorn, U., van Kaick, G. (1993), Studies with positron emission tomography after systemic administration of fluorine-18-uracil in patients with liver metastases from colorectal carcinoma. J Nucl Med., 34, 1075-1081.

Dimitrakopoulou-Strauss, A., Strauss, L. G., Schlag, P., Hohenberger, P., Mohler, M., Oberdorfer, F., van Kaick, G. (1998), Fluorine-18-fluorouracil to predict therapy response in liver metastases from colorectal carcinoma. J Nucl Med., 39, 1197-1202.

DNA.

(2005),

http://www.pbs.org/wgbh/nova/photo51/.

Double helix at 50 (Cover page). (2003), Nature, 422 (6934), 787-929.

Dougan, H., Hobbs, J. B., Weitz, J. I., Lyster, D. M. (1997), Synthesis and radioiodination of a stannyl oligodeoxyribonucleotide. Nucleic Acids Res., 25, 2897-2901.

Dougan, H., Weitz, J. I., Stafford, A. R., Gillespie, K. D., Klement, P., Hobbs, J. B., Lyster, D. M. (2003), Evaluation of DNA aptamers directed to thrombin as potential thrombus imaging agents. Nucl Med Biol., 30, 61-72.

Elion G. B. (1980), The chemotherapeutic exploitation of virus-specified enzymes. $A d v$ Enzyme Regul.,18, 53-66.

Eulberg, D., Klussmann, S. (2003), Spiegelmers: biostable aptamers. Chembiochem., 4, 979-983. Review.

Fowler, J. S., Finn, R. D., Lambrecht, R. M., Wolf, A. P. (1973), The synthesis of 18 F-5-fluorouracil. J Nucl Med., 14, 63-64.

Franklin, R., Gosling, R. G. (1953), Molecular Configuration in Sodium Thymonucleate. Nature, 171, 740-741.

Grierson, J. R., Schwartz, J. L., Muzi, M., Jordan, R., Krohn, KA. (2004), Metabolism of 3'-deoxy-3'$\left[{ }^{18}\right.$ F]fluorothymidine in proliferating A549 cells: validations for positron emission tomography. $\mathrm{Nucl}$ Med Biol., 31, 829-37.

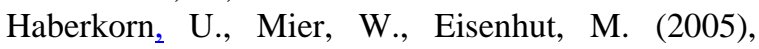
Scintigraphic imaging of gene expression and gene transfer. Curr Med Chem., 12, 779-794. Review.

Heidelberger, C., Chaudhuri, N. K., Danneberg, P., Mooren, D., Griesbach, L., Duschinsky, R., Schnitzer, R. J., Pleven, E., Scheiner, J. (1957), Fluorinated pyrimidines, a new class of tumourinhibitory compounds. Nature, 179, 663-666.
Heidelberger, C., Danenberg, P. V., Moran, R. G. (1983), Fluorinated pyrimidines and their nucleosides. Adv Enzymol Relat Areas Mol Biol., 54, 58-119.

Helmling, S., Moyroud, E., Schroeder, W., Roehl, I., Kleinjung, F., Stark, S., Bahrenberg, G., Gillen, C., Klussmann, S., Vonhoff, S. (2003), A new class of Spiegelmers containing 2'-fluoro-nucleotides. Nucleosides Nucleotides Nucleic Acids, 22, 10351038.

Hnatowich, D. J. (1996), Pharmacokinetics of 99mTc-labeled oligonucleotides. Quart. J Nucl Med., 202-208. Review.

Hnatowich, D. J., Mardirossian, G., Fogarasi, M, Sano, T., Smith, C. L., Cantor, C. R., Rusckowski, M., Winnard, P. (1996), Comparative properties of a technetium-99m-labeled single-stranded natural DNA and a phosphorothioate derivative in vitro and in mice. J Pharmacol Exp Ther., 276, 326-334.

Hnatowich, D. J., Winnard, P., Virzi, F., Fogarasi, M., Sano, T., Smith, C. L., Cantor, C. R., Rusckowski, M. (1995), Technetium-99m labeling of DNA oligonucleotides. J Nucl Med., 36, 23062314.

Iwashina, T., Tovell, D. R., Xu, L., Tyrrell, D. L., Knaus, E. E., Wiebe, L. I. (1988), Synthesis and antiviral activity of IVFRU, a potential probe for the non-invasive diagnosis of herpes simplex encephalitis. Drug Des Deliv., 3, 309-321.

Kaihatsu, K., Janowski, B. A., Corey, D. R. (2004) Recognition of chromosomal DNA by PNAs. Chem Biol., 11, 749-758.

Klussmann, S., Nolte, A., Bald, R. V., Erdmann, A., Furste, J. P. (1996), Mirror-image RNA that binds D-adenosine. Nat. Biotechnol., 14, 1112-1115.

Koizumi, $_{2}$ M. (2004), 2'-O,4'-C-Ethylene-bridged nucleic acids (ENA) as next-generation antisense and antigene agents. Biol Pharm Bull., 27, 453456.

Kurreck, J. (2003), Antisense technologies.. Improvement through novel chemical modifications. Eur J Biochem., 270, 1628-1644.

Langen, P., Etzold, G., Hintsche, R., Kowollik, G. (1969), 3'-Deoxy-3'-fluorothymidine, a new selective inhibitor of DNA-synthesis. Acta Biol Med Ger., 23, 759-766.

Langenbach, R. J., Danenberg, P. V., Heidelberger, C. (1972), Thymidylate synthetase: mechanism of inhibition by 5-fluoro-2'-deoxyuridylate. Biochem Biophys Res Commun., 48, 1565-1571.

Lawes, D., Taylor, I. (2005), Chemotherapy for colorectal cancer-an overview of current management for surgeons Eur. J Surgical Oncol., (in Press doi:10.1016/j.ejso.2005.03.015). 
Lewis, M. R., Jia, F., Gallazzi, F., Wang, Y., Zhang, J., Shenoy, N., Lever, S. Z., Hannink, M. (2002), Radiometal-labeled peptide-PNA conjugates for targeting bcl-2 expression: preparation, characterization, and in vitro mRNA binding. Bioconjug Chem., 13, 1176-1180.

Liu, G., Mang'era, K., Liu, N., Gupta, S., Rusckowski, M., Hnatowich, D. J. (2002), Tumor pre-targeting in mice using technetium-99m labeled morpholinos, a DNA analogue. J Nucl Med., 43, 384-391.

Mang'era, K. O., Liu, G., Wang, Y., Rusckowski, M., Hnatowich, D. J. (2001), Initial investigation of ${ }^{99 \mathrm{~m}}$ Tc-labeled morpholinos for radiopharmaceutical applications. Eur J Nucl Med., 28, 1682-1689.

Mankoff, D. A., Shields, A. F., Krohn, K. A. (2005), PET imaging of cellular proliferation. Radiol Clin North Am., 43, 153-167.

Matthes, E., Lehmann, C., Scholz, D., Rosenthal, H. A., Langen, P. (1988), Phosphorylation, anti-HIV activity and cytotoxicity of 3'-fluorothymidine. Biochem Biophys Res Commun., 153, 825-831.

Miescher, J. F. (1871), title and place of publication unknown. Miescher's 1869 work was not published until 1871. Dictionary of Scientists, 1999.

Muzi, M., Vesselle, H., Grierson, J. R., Mankoff, D. A., Schmidt, R. A., Peterson, L., Wells, J. M., Krohn, K. A. (2005), Kinetic analysis of 3'-deoxy3'-fluorothymidine PET studies: validation studies in patients with lung cancer. $J$ Nucl Med., 46, 274282.

Nielsen, P. E., Egholm, M., Berg, R. H., Buchardt, O. (1991), Sequence-selective recognition of DNA by strand displacement with a thymine-substituted polyamide. Science, 254, 1497-1500.

Paans, A. M. J., Vaalburg, W., Woldring, M. G. 1985, A comparison of the sensitivity of PET and NMR for in vivo metabolic imaging. Eur $\mathrm{J} \mathrm{Nucl}$ Med., 11: 73-75.

Panyutin, I. G., Sedelnikova, O. A., Karamychev, V. N., Neumann, R. D. (2003), Antigene radiotherapy: targeted radiodamage with ${ }^{125}$ I-labeled triplexforming oligonucleotides. Ann N Y Acad Sci., 1002, 134-140.

Park, J. W., Benz, C. C., Martin, F. J. (2004), Future directions of liposome- and immunoliposomebased cancer therapeutics. Semin Oncol. 31(Suppl 13), 196-205. Review.

Pellestor, F., Paulasova, P. (2004), The peptide nucleic acids, efficient tools for molecular diagnosis. Int J Mol Med., 13, 521-525.

Pestourie, C., Tavitian, B., Duconge, F. (2005), Aptamers against extracellular targets for in vivo applications. Biochimie, [Jun 14; Epub ahead of print].

Prusoff, W. H. (1959), Synthesis and biological activities of iododeoxyuridine, an analog of thymidine. Biochim Biophys Acta, 32, 295-296.
Prusoff, W. H., Holmes, W. L., Welch, A. D. (1953), Non-utilization of radioactive iodinated uracil, uridine, and orotic acid by animal tissues in vivo. Cancer Res., 13, 221-226.

Roivainen, A., Tolvanen, T., Salomaki, S., Lendvai, G., Velikyan, I., Numminen, P., Valila, M., Sipila, H., Bergstrom, M., Harkonen, P., Lonnberg, H., Langstrom. B. (2004), ${ }^{68}$ Ga-labeled oligonucleotides for in vivo imaging with PET. $J$ Nucl Med., 45, 347-355.

Schrödinger, E. (1944), What is Life? Through (2005), http://dieoff.org/page150.htm.

Seddon, B. M., Workman, P. (2003), The role of functional and molecular imaging in cancer drug discovery and development. Br J Radiol., 76, 128138.

Sedelnikova, O. A., Karamychev, V. N., Panyutin, I. G., Neumann, R. D. (2002), Sequence-specific gene cleavage in intact mammalian cells by ${ }^{125} \mathrm{I}-$ labeled triplex-forming oligonucleotides conjugated with nuclear localization signal peptide. Antisense Nucleic Acid Drug Dev., 12, 43-49.

Semnani, E. S., Wang, K., Adelstein, S. J., Kassis, A. I. (2005), 5-[ $\left.{ }^{123} \mathrm{I} /{ }^{125} \mathrm{I}\right]$ Iodo-2'-deoxyuridine in metastatic lung cancer: Radiopharmaceutical formulation affects targeting. J Nucl Med., 46, 800806.

Shi , N., Boado, R. J., Pardridge, W. M. (2000), Antisense imaging of gene expression in the brain in vivo. Proc Natl Acad Sci USA., 97, 1470914714.

Shields, A. F., Grierson, J. R., Dohmen, B. M., Machulla, H-J., Stayanoff, J. C., Lawhorn-Crews, J. M., Obradovich, J. E., Muzik, O., Mangner, T. J. (1998), Imaging proliferation in vivo with $\left[{ }^{18} \mathrm{~F}\right] \mathrm{FLT}$ and positron emission tomography. Nature Med., 4, 1334-1336.

Simeoni, F., Morris, M. C., Heitz, F., Divita, G. (2005), Peptide-Based Strategy for siRNA Delivery into Mammalian Cells. Methods Mol Biol., 309, 251-360.

Summerton, J., Weller, D. (1997), Morpholino antisense oligomers: Design, preparation, and properties. Antisense Nucleic Acid Drug Dev., 7, 187-195.

Sun, X., Fang, H., Li, X., Rossin, R., Welch, M. J., Taylor, J. S. (2005), MicroPET imaging of MCF-7 tumors in mice via unr mRNA-targeted peptide nucleic acids. Bioconjug Chem., 16, 294-305.

Taylor, M. F., Paulauskis, J. D., Weller, D. D., Kobzik, L. (1996), In vitro efficacy of morpholinomodified antisense oligomers directed against tumor necrosis factor-alpha mRNA. J Biol Chem., 271, 17445-52.

The Dictionary of Cell and Molecular Biology. (2005), http://www.mblab.gla.ac.uk/ julian/Dict.html. 
Tian, X., Aruva, M. R., Rao, P. S., Qin, W., Read, P., Sauter, E. R., Thakur, M. L., Wickstrom, E. (2003), Imaging oncogene expression. Ann N Y Acad Sci., 1002, 165-88.

Tjuvajev, J. G., Finn, R., Watanabe, K., Joshi, R., Oku, T., Kennedy, J., Beattie, B., Koutcher, J., Larson, S., Blasberg, R. G. (1996), Noninvasive imaging of herpes virus thymidine kinase gene transfer and expression: a potential method for monitoring clinical gene therapy. Cancer Res., 56, 4087-95.

Tovell, D. R., Samuel, J., Mercer, J. R., Misra, H. K., $\mathrm{Xu}, \mathrm{L} .$, Wiebe, L. I., Tyrrell, D. L., Knaus, E. E. (1988), The in vitro evaluation of nucleoside analogues as probes for use in the noninvasive diagnosis of herpes simplex encephalitis. Drug Des Deliv., 3, 213-21.

Toyohara, J., Gogami, A., Hayashi, A., Yonekura, Y., Fujibayashi, Y. (2003), Pharmacokinetics and metabolism of $5-{ }^{125}$ I-iodo-4'-thio-2'-deoxyuridine in rodents. $J$ Nucl. Med., 44, 1671-1676.

Urban $_{2}$ E., Noe, C. R. (2003), Structural modifications of antisense oligonucleotides. Farmaco., 58, 243-58. Review.

Vaidyanathan, G., Larsen, R. H., Zalutsky, M. R. (1996), 5- ${ }^{211}$ At $]$ astato-2'-deoxyuridine, an alpha particle-emitting endoradiotherapeutic agent undergoing DNA incorporation. Cancer Res., 56, 1204-1209.

Watson, J. D., Crick, F. H. C. (1953), A structure for deoxyribose nucleic acid. Nature, 171, 737-738.

Wells, J. M., Mankoff, D. A., Eary, J. F., Spence, A. M., Muzi, M., O'Sullivan, F., Vernon, C. B., Link, J. M., Krohn, K. A. (2002a), Kinetic analysis of 2$\left[{ }^{11} \mathrm{C}\right]$ thymidine PET imaging studies of malignant brain tumors: preliminary patient results. Mol Imaging, 1, 145-150.

Wells, J. M., Mankoff, D. A., Muzi, M., O'Sullivan, F., Eary, J. F., Spence, A. M., Krohn, K. A. (2002b), Kinetic analysis of $2-\left[{ }^{11} \mathrm{C}\right]$ thymidine PET imaging studies of malignant brain tumors: compartmental model investigation and mathematical analysis. Mol Imaging, 1, 151-159.
Wiebe, L. I. (2001), FDG Metabolism: Quaecumque Sunt Vera.... J. Nucl. Med. 42, 1679-1681.

Wiebe, L. I., Knaus, E. E. (2001), Nucleosides in Gene Therapy Imaging. Current Pharmaceutical Design 7, 1893-1906.

Wiebe, L. I., Knaus, E. E., Morin, K. W. (1999), Radiolabelled pyrimidine nucleosides to monitor the expression of HSV-1 thymidine kinase in gene therapy. Nucleosides Nucleotides, 18, 1065-1066.

Wilbur, D. S., Chyan, M-K., Hamlin, D. K., Hobbs, J. (2005), Synthesis and radioiodination of a PNA containing an $\left[{ }^{125} \mathrm{I}\right]$ iodouracil moiety. J Radiolab Comp Radiopharmaceuticals, 48(S1), S302.

Yaghoubi, S. S., Barrio, J. R., Namavari, M., Satyamurthy, N., Phelps, M. E., Herschman, H. R., Gambhir, S. S. (2005), Imaging progress of herpes simplex virus type 1 thymidine kinase suicide gene therapy in living subjects with positron emission tomography. Cancer Gene Ther., 12, 329-339.

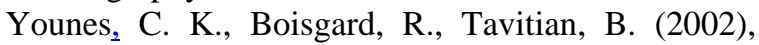
Labelled oligonucleotides as radiopharmaceuticals: pitfalls, problems and perspectives. Curr Pharm Des., 8, 1451-1466. Review.

Zhang, Y. R., Zhang, Y. X., Cao, W., Lan, X. L. (2005), Uptake Kinetics of 99mTc-MAG3Antisense Oligonucleotide to PCNA and Effect on Gene Expression in Vascular Smooth Muscle Cells. J Nucl Med., 46,1052-1058.

Zheng, J., Tan, T., Pan, W., Zhang, C. (2003a), [Study on the antisense inhibition effect of liposome-mediated radiolabled antisense oligonucleotides of c-myc mRNA]. Sichuan Da Хие Хие Bao Yi Xue Ban., 34, 413-416. in Chinese.

Zheng, J., Tan, T., Pan, W., Zhang, C. (2003b), [Preparation of liposome-mediated $99 \mathrm{~m}$ technetium-labeled antisense oligonucleotides of cmyc mRNA]. Sheng Wu Yi Xue Gong Cheng Xue Za Zhi., 20, 704-707. in Chinese.

Received: November 18, 2005; Revised: March 28, 2006; Accepted: March 16, 2007. 
PÁGINA

EM

BRANCO 